\title{
Been There, Done That: The Margin of Appreciation and International Law
}

\author{
Eirik Bjorge*
}

\begin{abstract}
The margin of appreciation, as a doctrine of international law, has a great future behind it. It was once thought to be the panacea that would solve international law's problems, but has in fact diminished in importance in international law. Contrary to what is often argued, the doctrine of the margin of appreciation originated in early public international law, not in Continental domestic public law. In the course of the twentieth century, international law discarded the doctrine. The preferred standard of review, as the International Court set out in Whaling in the Antarctic, is 'an objective one. In the sphere where the margin of appreciation is most famously in operation, the law of European human rights, it is being supplanted by the doctrine of subsidiarity. The margin of appreciation is, in international law, an aberration. It is time we treated it as such.

This article was presented as the inaugural CJICL Young Scholars' Lecture in February 2015, held at the Lauterpacht Centre for International Law, University of Cambridge.
\end{abstract}

\section{Keywords}

Margin of Appreciation, Deference, Standard of Review, International Courts and Tribunals, European Convention on Human Rights

\section{Introduction}

Until recently, the doctrine of the margin of appreciation was widely thought to be something of a panacea, a quick fix to many a problem in public international law. It has been conceived of as a doctrine to be given application in practically all spheres of international law, at least in the sense that it should be recognised as having general application in international law. Those who have made this argument have told us that international law ought to take inspiration from the jurisprudence of the European Court

* DPhil, University of Oxford; Shaw Foundation Junior Research Fellow in Law, Jesus College, University of Oxford (UK). This article is dedicated to Dame Rosalyn Higgins DBE QC, who in her years on the UN Human Rights Committee made sure the margin was never adopted there. 
of Human Rights (ECtHR). For it is there that the margin has had the greatest impact and enjoyed the greatest success and longevity. The margin of appreciation is a form of legal discretion granted by an international court to the respondent, recognising that the respondent state can be presumed to be best qualified to appreciate the necessities of a particular situation affecting its jurisdiction. ${ }^{1}$

One leading commentator, Yuval Shany, argued that the doctrine should be given full recognition by the International Court of Justice (ICJ) in the types of case in which it has, famously, been applied by the ECtHR. ${ }^{2}$ To the extent that the jurisprudence of the ICJ is not aligned, in this respect, with the application of the doctrine by the European Court, Shany argued, the International Court should take steps to rectify this state of affairs. ${ }^{3}$ He was hopeful that the International Court would, by adopting the doctrine, 'eventually join the prevailing trend, and replace the façade of objective normative guidance adopted in several of its recent decisions with a more nuanced and conducive approach. ${ }^{4}$ Other leading publicists have taken much the same view. ${ }^{5}$

Taking issue with this account, I will set out to demonstrate why, in the recent past, international courts and tribunals have resisted the doctrine. The argument is very simple. The leading publicists I just mentioned have argued that international law should take a leaf out of the book of the ECtHR and accord to respondent states a margin of appreciation in relation to determinations made by the state under international law.

Conventional wisdom is that the ECtHR took the doctrine of the margin of appreciation from German and French public law. ${ }^{6}$ The received wisdom as to the genealogy of the doctrine, repeated by practically everyone who has written on the topic, is: continental domestic public law, European Court, and then, they have been and remain hopeful, international law.

As I will argue, however, there are at least two problems with this genealogy. The institutions of the European Convention, in the 1940s, 1950s, and 1960s never in the first place took the doctrine from domestic Continental law, for the simple reason that the doctrine never existed there. The doctrine came instead from public international law, the public international law of the early twentieth century. And, importantly, at

1 J Crawford, Brownlie's Principles of Public International Law (8th edn, OUP 2012) 666.

2 Y Shany, 'Toward a General Margin of Appreciation Doctrine in International Law?' (2006) 16 EJIL 907, 939. See, however, the early criticism - from which the present contribution draws inspiration-by $\mathrm{R}$ Higgins, 'Derogations under Human Rights Treaties' (1976-77) 48 BYIL 296-97.

3 Y Shany (n 2) 931.

4 Y Shany (n 2) 939-40.

5 E Cannizzaro and B Bonafè, 'Beyond the Archetypes of Modern Legal Thought: Appraising Old and New Forms of Interaction between Legal Orders' in M Maduro, K Tuori and S Sankari (eds), Transnational Law: Rethinking European Law and Legal Thinking (CUP 2014) 78, 84-88; Dissenting Opinion of Judge Cot, The Volga (Russian Federation v Australia) (Application for Prompt Release) (2002) 126 ILR 433, 469-70.

6 See SD Murphy, 'Does International Law Obligate States to Open Their National Courts to Persons for the Invocation of Treaty Norms That Protect or Benefit Persons?' in D Sloss (ed), The Role of Domestic Courts in Treaty Enforcement: A Comparative Study (CUP 2009) 76; B Simpson, Human Rights and the End of Empire: Britain and the Genesis of the European Convention (OUP 2001) 1001-05; A Legg, The Margin of Appreciation in International Human Rights Law (OUP 2012) 3. 
the time when the Strasbourg organs, principally its Commission and Court, adopted the doctrine, public international law was about to jettison the margin of appreciation altogether.

The conclusion which, for me, arises from this messy picture, then, is that we should not be surprised that the ICJ recently in Oil Platforms ${ }^{7}$ and Whaling in the Antarctic, ${ }^{8}$ but also other international tribunals such as the International Tribunal for the Law of the Sea and ad hoc arbitral tribunals, have resisted adopting the doctrine. To international law-or what we could with a contested term call general international law-the slightly tired idea of the margin of appreciation is decidedly old hat. International law has been there, it has done that.

\section{Putative domestic law ancestry of the margin of appreciation}

It is, as I just explained, often claimed that the Strasbourg doctrine of the margin of appreciation was a concept taken from national law, both in the late 1940s when it was first suggested that the margin of appreciation should be inserted into the Convention itself, and in the late 1950s, when it actually appeared in the jurisprudence of the European Commission of Human Rights.

Many authors have held that the doctrine of the margin of appreciation originated from French and German administrative law. ${ }^{9}$ It is no exaggeration to say that this has become the conventional wisdom. It is far from clear, however, that this assertion withstands any serious scrutiny. Several factors at least suggest that the doctrine of the margin of appreciation was taken not so much from domestic law as from general international law.

First of all, the drafting history of the European Convention on Human Rights (ECHR) seems to point in that direction. During the drafting of what would become the European Convention, the Maxwell-Fyfe and Teitgen Committee, chaired by Sir David Patrick Maxwell-Fyfe, later Lord Kilmuir LC, and Pierre-Henri Teitgen, professor of international law and later French Minister of Justice, raised the idea of devolving responsibility to member states for agreeing on detailed definitions. Rapporteur Teitgen thus suggested that an international convention was to establish and give no more than general definitions of a list of guaranteed freedoms. ${ }^{10}$ Each state had the right to determine, in respect of itself, the practical means for the exercise of the liberties guaranteed by the Convention.

This approach he explained in terms of, in the French original, 'liberté d'appréciation':

Each country shall, through its own legislation, determine the conditions in which these guaranteed liberties shall be exercised within its territory, and, in defining the practical

7 Oil Platforms (Iran v US) [2003] ICJ Rep 2003161.

8 Whaling in the Antarctic (Australia v Japan; New Zealand intervening) [2014] ICJ Rep 2014.

9 See $\mathrm{n} 6$ above.

10 Travaux préparatoires to the ECHR, Seventeenth Sitting, 7 September 1949 (M Teitgen) 1150. 
conditions for the operation of these guaranteed liberties, each country shall have a very wide freedom of action (une très large liberté d'appréciation). ${ }^{11}$

In the end the framers decided not to include any mention of any liberté or marge d'appréciation in the provisions of the Convention. It was dealt with systemically instead, through generic terms.

The phrase would instead make its first appearance in the jurisprudence of the European Commission of Human Rights in the 1958 Cyprus Case. ${ }^{12}$

As I adumbrated above, many leading authors have asserted, usually I fear with no more than threadbare proof that the marge d'appreciation, came from Continental administrative law. This is the assertion put forward by the great AWB Simpson in his Human Rights and the End of Empire, ${ }^{13}$ later unblushingly repeated by margin-ofappreciation scholars of renown.

On the European Commission in 1958 sat, among others, the German lawyer, Adolf Süsterhehn, a domestic constitutional lawyer, who, having joined the Commission just before it adopted the margin-of-appreciation approach to the question of whether the respondent state in Cyprus could derogate under article 15, is alleged to have introduced into the jurisprudence of the Strasbourg organs the margin of appreciation. Post hoc ergo propter hoc seems to be the conclusion that Simpson draws in this connection.

But is it a hallmark of German administrative and constitutional law that the courts accord to administrative agencies margins of appreciation? No. There are in my view two reasons why this conclusion should be resisted.

First comes the reason that, in general, judicial review in German administrative and constitutional law is perhaps the most searching of all European legal systems. ${ }^{14}$ Secondly, it is not correct that a doctrine similar to the margin of appreciation was ever allowed to take root in German law, and certainly not by the time, in the late 1950s, when Süsterhehn and his Commission colleagues in the Cyprus Case adopted it. ${ }^{15}$

As Birgit Schlütter has concluded in relation to German law in this regard, 'the margin of appreciation doctrine of the [European Court] finds no parallel at the national level.' ${ }^{16}$ Against this background, the conclusion that the doctrine was taken from German law should perhaps cautiously be resisted.

It has also been suggested that the concept of the margin of appreciation is of specifically French origin. After all, a French word. Some authors have claimed that the

11 ibid.

12 Greece v United Kingdom (Cyprus Case) App no 176/56, (1958) 2 Yearbook of the European Convention on Human Rights 174, 174-76. See the foresight shown in this connection by the critical remarks of Higgins (n 2).

13 See $\mathrm{n} 7$ above.

14 See eg G Nolte, 'General Principles of German and Administrative Law: A Comparison in Historical Perspective’ (1994) 57 MLR 191, 197.

15 See 15 BVerwGE 207, 208; 23 BVerwGE 194, 200-01; 24 BVerwGE 65; 31 BVerwGE 149, 152; 35 BVerwGE 67, 72-73. See further M Singh, German Administrative Law in Common Law Perspective (2nd edn, Springer 2002) 177-78.

16 B Schlütter, 'Germany’s Dialogue with Strasbourg' (2012) 13 GLJ 757, 769. 
Conseil d'Etat had used in its jurisprudence the phrase marge d'appréciation, and that this jurisprudence was the inspiration for the Strasbourg institutions taking up this doctrine. It can be stated with certainty that that last assertion is not entirely correct. The term appeared in the jurisprudence of the Conseil d'Etat for the first time in 1977, ${ }^{17}$ after the Strasbourg organs had begun relying on the margin of appreciation and after the ECHR had begun to make its presence felt within French law.

Even more importantly, however, as the Cambridge Professor of Comparative Law CJ Hamson explained to English-speaking audiences in his classic 1954 treatise comparing English and French administrative law Executive Discretion and Judicial Control: ${ }^{18}$ French administrative law is probably the least promising of all possible jurisdictions to look to for those who seek inspiration as to ways in which to broaden deference and discretion granted by courts to the government. Such a doctrine simply did not exist in French law.

On the whole, there is little evidence that the ECHR institutions received the doctrine of the margin of appreciation from German and French administrative law. A number of factors point towards a different genealogy.

\section{The margin of appreciation and its actual international law ancestry}

The origins of the concept of the margin of appreciation lay not so much in domestic law as in international law. This could be thought to be borne out already by the way in which Rapporteur Teitgen explained the approach chosen for the drafting of the European Convention referred to above:

elle consacre le principe traditionnel, et même fondamental en droit international public, selon lequel chaque pays a compétence pour organiser sur son territoire les modalités d'exercice et les conditions quotidiennes de fonctionnement des droits et des libertés garantis. ${ }^{19}$

Teitgen here seems to be saying that, in his view, the principle was adopted from his own field of scholarship-droit international public. Teitgen makes no mention of the putative domestic law ancestry.

He was right, in the late 1940s, to refer to the margin of appreciation as being 'traditional' and 'fundamental' in public international law. If one scrutinises the language adopted-and the tradition in the international law of the first half of the twentieth century of granting to states margins or powers of appreciation-it seems likely that the Strasbourg institutions took the inspiration for the margin of appreciation from general international law.

What then did that law say? The doctrine of liberté d'appréciation in international law surfaced perhaps most prominently in Spanish Zone of Morocco Claims, ${ }^{20}$ where

17 Conseil d'État, 7 October 1977, Sieur Gaillard Yves.

18 CJ Hamson, Executive Discretion and Judicial Control (Stevens \& Sons 1954).

19 Travaux préparatoires to the ECHR (n 10) 1150.

20 British Claims in the Spanish Zone of Morocco (Great Britain v Spain) (1925) 2 RIAA 615. 
the Tribunal was made up by Sole Arbitrator Max Huber, President of the Permanent Court of International Justice. As students of state responsibility will know, this classic of international law contains multitudes. But strangely, to my knowledge at least, no one has pointed to what the case has to say about the margin of appreciation.

The Tribunal determined that the appraisal of the necessity of certain impugned military actions at issue in the case lay, to a very large extent, not with the Tribunal but with the domestic authorities that had carried out those military actions. The Tribunal both explicitly used the terminology liberté d'appréciation and in actual fact deferred to national authorities in its necessity inquiry. The Tribunal concluded: 'The appreciation of necessity should be left in large measure to those who are called upon to act in difficult situations, and to their military superiors. 21 This was due to the fact that '[a] civilian court, and especially an international one, cannot intervene in this domain except in cases of manifest abuse of this liberty of appreciation. ${ }^{22}$ The Tribunal underscored that both the fact that the domestic authorities in question possessed greater expertise than the Tribunal, and the fact that the Tribunal was in international one, led to the conclusion that a 'liberty of appreciation' must be accorded to the Spanish authorities. Both in terms of the terminology used and in the reasons relied on this looks like nothing if not the precursor to the doctrine of the margin of appreciation.

Huber's approach in Spanish Zone of Morocco Claims of the issue of the applicable standard of review, in relation to standards of necessity or urgency, was relied upon by the Permanent Court of International Justice in Lighthouses Case between France and Greece, where it was determined that:

any grant of legislative powers generally implies the grant of a discretionary right to judge how far their exercise may be necessary or urgent. (...) It is a question of appreciating political considerations and conditions of fact, a task which the Government, as the body possessing the requisite knowledge of the (...) situation, is alone qualified to undertake. ${ }^{23}$

Other incidences of the doctrine of the margin of appreciation in the jurisprudence of $a d$ hoc Tribunals in the 1920 s-40s abound. ${ }^{24}$

And as late as in 1948, the ICJ in Admissions determined that, while article 4 of the Charter of the United Nations ${ }^{25}$ exhaustively prescribes the conditions for the admissions of new members, that provision did not 'forbid the taking into account of any factor which

21 ibid 645 ('Lappréciation de ces nécessités doit être laissée dans une large mesure aux personnes mêmes qui sont appelées à agir dans des situations difficiles, ainsi qu’à leurs chefs militaires').

22 ibid ('Une juridiction non militaire, et surtout une juridiction internationale, ne saurait intervenir dans ce domaine quén cas d'abus manifeste de cette liberté d'appréciation').

23 Lighthouses Case between France and Greece (France v Greece) (Judgment) PCIJ Rep Series A/B No 62, 22 ('faculté discrétionnaire d'apprécier la nécessité et l'urgence').

24 Acquisition of Polish Nationality (Advisory Opinion) PCIJ, 1923 PCIJ Rep Series B No 7, 9; Affaire de la dette publique ottomane (1925) 1 RIAA 529, 566-68; Différend SAIMI (Società per Azioni Industriale Marmi d'Italia)_Decisions No 4, 11, 19, 38 et 7013 (1948-50) RIAA 43, 45; Georges Pinson (France $v$ Mexico) (1928) 5 RIAA 327, 412.

25 Charter of the United Nations (adopted 26 June 1945, entered into force 24 October 1945) 892 UNTS 119. 
it is possible reasonably and in good faith to connect with [those] conditions', article 4 thus allowing for 'a wide liberty of appreciation' ('une large liberté d'appréciation'). ${ }^{26}$ These early incidences of the doctrine in the jurisprudence of international courts and tribunals are mirrored by the extensive reliance upon the doctrine of the margin of appreciation found in the writings of leading international lawyers in the 1920-30s. ${ }^{27}$

\section{The doctrine's disappearance in general international law}

Public international law would, however, from the end of the Second World War and onwards, undergo substantial change in respect of issues of sovereignty and the view of how acceptable doctrines of margins of appreciation really were in the intercourse of states. Like with many other changes in international law, the change happened incrementally and through accretion. Thus, as was seen above, the 1948 Admissions judgment still relied on the margin of appreciation.

Setting out what could be thought to be a new direction post Second World War, one major ruling that decisively moved away from the Spanish Zone of Morocco Claims approach was the Nuremberg judgment. ${ }^{28}$ The defendants had, in connection with the charge of German aggression against Norway, pleaded that Germany alone could decide as to whether the action 'was a necessity, and that in making her decision her judgment was conclusive. ${ }^{29}$ The Nuremberg Tribunal, however, determined tersely that 'whether action taken under the claim of self-defense was in fact aggressive or defensive must ultimately be subject to investigation and adjudication if international law is ever to be enforced. ${ }^{30}$ Gone was the Spanish Zone of Morocco Claims approach, according to which ' $\mathrm{t}$ ] he appreciation of necessity should be left in large measure to those who are called upon to act in difficult situations, and to their military superiors. ${ }^{31}$ In Nuremberg, no such margin of appreciation was left to the decision makers, or to their military superiors. As I will show, the same is the case in other postwar cases.

It could be asked, on this background, why the latter half of the twentieth century witnessed this emergent move away from the margin-of-appreciation approach?

Max Huber, having himself presided over Spanish Zone of Morocco Claims, observed in 1958 that, if international law was to develop, notions of sovereignty must inevitably in

26 Conditions of Admission of a State Membership in the United Nations (Article 4 of the Charter) (Advisory Opinion) [1948] ICJ Rep 57, 64.

27 See eg A Verdross, Les principes généraux du droit dans la jurisprudence internationale 52 Hague Recueil 195, 248 (1935); M Bourquin, Stabilité et mouvement dans lordre juridique international 64 Hague Recueil 354, 400 (1938); R Ago, Le délit international 68 Hague Recueil 419, 471 (1939).

28 Trial of the Major War Criminals before the International Military Tribunal, Nuremberg, Judgment, reproduced in (1947) 41 AJIL 172, 207; In re Goering (1946) 13 ILR 203, 210.

29 Trial of the Major War Criminals before the International Military Tribunal (n 28) 207.

30 ibid.

31 British Claims in the Spanish Zone of Morocco (n 20) 645. 
some measure give way. He underlined how in the chancelleries of the world exaggerated ideas of sovereignty had outlived themselves, at the expense of international cooperation:

Nobody will venture to assert that the international law of today, in spite of new directions in 1920 and 1946, is able to cope with the present world situation. The responsibility of all concerned with international law in the widest sense of the term, whether as politicians or scientists, is all the heavier. There is only one way to a new solution: coexistence. ${ }^{32}$

The former Judge concluded that 'the idea of sovereignty, which flattered and served the sense of power in big states and the desire for independence in small ones, must make way for an efficient and active community of nations. ${ }^{33}$ It is against this background that we should understand the development of the jurisprudence of the International Court in connection with the margin of appreciation, as the Court moved to disavow its deferential approach from earlier decades, preferring instead a more objective approach. The clearest examples of this development would come in Oil Platforms and Whaling in the Antarctic.

To stand on its head the exhortation by Shany quoted in the introduction, the International Court would move away from what Shany dubbed a 'nuanced and conducive approach' to what he saw as being no less than a 'façade of objective normative guidance. ${ }^{34}$ Thus, in an assessment of military necessity, the same consideration as had been at issue in Spanish Zone of Morocco Claims, the International Court in Oil Platforms did not accept the suggestion by the United States that the decision should not ultimately be subject to investigation and adjudication by the Court. On the US view, in the context of the case, 'a measure of discretion ("une certaine liberté d'appréciation") should be afforded to a party's good faith application of measures'. The Court, for its part, simply stated that:

the requirement of international law that measures taken avowedly in self-defence must have been necessary for that purpose is strict and objective, leaving no room for any 'measure of discretion' ('une certaine liberté d'appréciation'). ${ }^{35}$

In opting for a 'strict and objective test' instead of leaving room for a 'measure of discretion', or a margin of appreciation, the International Court in Oil Platforms plainly took the modern course of the Nuremberg Tribunal rather than the outmoded one of the Tribunal in Spanish Zone of Morocco.

A important concomitant development in the decline of the margin of appreciation in international law is the emerging focus on the reasons for which the respondent state had made its determination or applied the measure at issue.

32 M Huber, 'On the Place of the Law of Nations in the History of Mankind' in Symbolae Verzijl (Martinus Nijhoff 1958) 194-95.

33 ibid 195.

34 See $\mathrm{n} 2$ above.

35 Oil Platforms (n 7) 196. 
This is clear from Whaling in the Antarctic. ${ }^{36}$ At issue there was the interpretation of article VIII of the Whaling Convention, ${ }^{37}$ which provides that:

Notwithstanding anything contained in this Convention any Contracting Government may grant to any of its nationals a special permit authorizing that national to kill, take and treat whales for purposes of scientific research [en vue de recherches scientifiques] subject to such restrictions as to number and subject to such other conditions as the Contracting Government thinks fit, and the killing, taking, and treating of whales in accordance with the provisions of this Article shall be exempt from the operation of this Convention.

Japan had in its oral pleadings before the Court argued that there existed in international law a general doctrine of the margin of appreciation. Another whaling state, Norway, had taken a particularly strong stance in this regard, its Minister of Fisheries and Coastal Affairs, Lisbeth Berg-Hansen, arguing in a statement to the Norwegian Parliament that, on the Norwegian view, the state of nationality must have a 'very broad margin of appreciation. $^{38}$

Rejecting the argument that the Court should advert to a general doctrine of the margin of appreciation, the Court held that article VIII gave discretion to a state party under the convention to reject the request for a special permit or to specify the conditions under which a permit would be granted. Nonetheless, observed the Court, whether the killing, taking and treating of whales pursuant to a requested special permit was for purposes of scientific research 'cannot depend simply on that State's perception. ${ }^{39}$ As is clear from the Court's choice of words, there is scope within this approach for more or less latitude accorded to the state; the analysis below explains where on the continuum of more or less latitude the Court decided to ground its review of the impugned determinations.

The Court observed that in reviewing the grant of a special permit authorising the killing, taking and treating of whales, the Court would assess, first, whether the program under which these activities occurred had involved scientific research. Secondly, the Court would consider if the killing, taking and treating of whales was 'for purposes of' scientific research by examining whether, in the use of lethal methods, the program's design and implementation were 'reasonable in relation to achieving its stated objectives'. The Court pointed out that 'this standard of review is an objective one. ${ }^{30}$

International Convention for the Regulation of Whaling (adopted 2 December 1946, entered into force 10 November 1948) 161 UNTS 72.

38 Norwegian Minister of Fisheries and Coastal Affairs, 'Scientific Research on Whales' (2013) <http:// www.regjeringen.no/en/archive/Stoltenbergs-2nd-Government/Ministry-of-Fisheries-and-Coastal-Affair/ Nyheter_og_pressemeldinger/nyheter/2013/scientific-research-on-whales.html?id=731449> accessed 12 April 2015: 'The terms of Article VIII are unambiguous. The decision-making powers in this matter rest with the State party concerned. (...) The State Party concerned retains a very broad margin of appreciation (deciding such restrictions as the State "thinks fit"). The discretion to be exercised is not qualified by references to criteria of "necessity", "proportionality" or other similar requirements.'

39 Whaling in the Antarctic (n 8) para 61.

40 ibid para 67. 
Thus the Court decidedly declined to accept Japan's proposed margin-of-appreciation approach to asking, instead, whether the design and implementation of the program at issue were 'reasonable in relation to achieving its stated objectives. ${ }^{41}$

Why did the Court choose this approach? It seems that, in the first place, the Court needed to avoid saying that Japan had acted in bad faith, simply because a finding to this effect by 'the principal judicial organ of the United Nations ${ }^{42}$ would be very difficult for a sovereign state to accept. In the second place, clearly did not want to get embroiled in defining what is 'science.' The Court, in the third place, and I think most importantly, wanted to avoid giving its imprimatur to the doctrine of the margin of appreciation.

The answer to why, in the postwar period, international courts and tribunals have taken this approach, could be summed up in the answer given by the Nuremberg Tribunal when it observed that whether the measure taken in that case was lawful or not 'must ultimately be subject to investigation and adjudication if international law is ever to be enforced. ${ }^{33}$ International courts and tribunals' according to states a margin of appreciation simply undermines, in the context of a treaty such as the Whaling Convention, the regulations the convention sets out, thus weakening the obligations, and concomitant rights, undertaken by, and accorded to, the member states. In international law, the granting of a margin of appreciation to one state may, by effectively giving to that state a free rein vis-à-vis another state, runs the risk of enlarging the sovereignty of the former by encroaching upon the sovereignty of the latter. Against this background, it could be concluded that, as regards public international law, the ground has been pulled away from under the doctrine of the margin of appreciation. The doctrine, originating in the public international law of the period of approximately 1900-50, has, in the period approximately 1950-2000, been reduced to vanishing point.

\section{Conclusion}

I have ventured to show that, as a doctrine of international law, the margin of appreciation has a great future behind it. To international law, the margin of appreciation is decidedly old hat. International law, having originated the doctrine, jettisoned it in the early postwar years. Those who think they have something to teach international law by arguing that it adopt the by now fairly hackneyed doctrine of the margin of appreciation are late by approximately 60 years.

41 ibid paras $67,97$.

42 Charter of the United Nations (n 25) art 92.

43 Trial of the Major War Criminals before the International Military Tribunal (n 28) 207. 